\title{
Plant, Soil and Water Pollution Due to Tannery Effluent a Case Study From Sheb Tannery, P.L.C, Wukro Tigray, Ethiopia
}

\author{
Teklit Gebregiorgis Amabye \\ Department of Chemistry, College of natural and computational science, Mekelle University, Mekelle Tigary, Ethiopia
}

Email address:

kidanberhe13@gmail.com

To cite this article:

Teklit Gebregiorgis Amabye. Plant, Soil and Water Pollution Due to Tannery Effluent a Case Study From Sheb Tannery, P.L.C,Wukro Tigray, Ethiopia. Science Journal of Analytical Chemistry. Vol. 3, No. 5, 2015, pp. 47-51. doi: 10.11648/j.sjac.20150305.11

\begin{abstract}
The effect of industrial effluent contaminated sewage water on the content of micro and potentially toxic elements in soils and potato plants was studied. The elemental composition of the sewage water changed due to the contamination from the tannery effluents. The increase in Cr was so dramatic. It increased from $2.7 \mathrm{mg} / \mathrm{kg}$ in the control soils to $14 \mathrm{mg} / \mathrm{kg}$ in soils irrigated with the contaminated water. The soils of the study area were generally light textured and there was a build up to 30 $\mathrm{cm}$ or lower depth. The release of wastewater into the environment polluted not only the irrigated soils but also plants growing in these irrigated soils such as potatoes and onion. Due to disposal of industrial effluents, the waste waters have higher contents of $\mathrm{Cu}$ by 42 times, Fe by 155, Mn by $98, \mathrm{Zn}$ by 31, Al by 50, As by 4, Cr by1400 and Ni by 52 times over the tube well water We observed that the concentrations of the contaminating elements were higher in potato and onion the buildup of $\mathrm{Cu}$ and $\mathrm{Zn}$ was higher in soils than in the vegetables grown in the contaminated soils suggesting a decreased absorption by the plants. Contrary to $\mathrm{Cu}$ and $\mathrm{Zn}$, the absorption of $\mathrm{Cr}$ and $\mathrm{Ni}$ by potato plants and its distribution in inedible non-edible parts was proportional to its build up in soil.
\end{abstract}

Keywords: Sewage Water, Micronutrients, Toxic Elements, Potato

\section{Introduction}

Tannery effluents are ranked as the highest pollutants among all the industrial wastes. It is estimated that in Ethiopia alone about 200-300t of chromium is released into the environment annually from tannery industries, with chromium concentrations ranging between 2000 and 5000 $\mathrm{mg} / \mathrm{l}$ in the aqueous effluent compared to the recommended permissible limits of $2 \mathrm{mg} / \mathrm{l}$ (Westcott, FAO 1985) the tanning industries are especially large contributors of chromium pollution in Ethiopia. Two types of effluents are discharged during the tanning process: vegetable tanning, which does not contain chromium, and chrome tanning, which contains chromium (Alemtsehaye, 2002). Leather processing requires large amount of chemicals like sodium chloride, chromium sulphate, calcium salts, ammonium salts, sodium sulphide, acids, alkalis, fat, liquor, and organic dyes. However, one of the major emerging environmental problems in the tanning industry is the disposal of chromium contaminated sludge produced as a by-product of wastewater treatment. Tannery effluents severely affect the mitotic process and reduce seed germination in extensively cultivated pulse crops (Westcott, FAO 1985). At high concentrations (need to be specific) chromium is toxic, mutagenic, carcinogenic, and teratogenic (Alemtsehay 2002). Chromium exists in oxidation states of $+2,+3$, and +6 . The trivalent oxidation state is the most stable form of chromium and is essential to mammals in trace concentration and relatively immobile in the aquatic system due to its low water solubility. The hexavalent chromium is much more toxic to many plants, animals, and bacteria inhabiting aquatic environments. Chromium resistant microorganisms from chromium contaminated soil and sediments have been isolated. In this study, we will be investigating the effect of Sheba tannery effluents on the surrounding environment specifically soil, plant and water bodies.

\section{Background Information}

The environment is under increasing pressure from solid and liquid wastes emanating from the leather industry. These are inevitable by-products of the leather manufacturing 
process and cause significant pollution unless treated in some way prior to discharge.

In some instances, liquid waste is discharged into sewage systems (indirect discharge) where it undergoes full-scale treatment before being returned to the environment via surface waters. Where effluent is discharged direct into streams and rivers, it needs to be of higher quality as the environment is sensitive and highly susceptible to damage. The greater the volume of the effluent compared to the volume of surface water, the higher the quality of the effluent demanded by the environment (Westcott, FAO 1985). Discharge limits are set with the objective of protecting the environment. The levels of the Different pollutants in effluent are determined in two ways. The limits are:

(a) Based on standards which have been widely applied and found generally acceptable. This method, however, tends to ignore specific individual situations.

(b) Set along the lines of mass-balance, whereby the quality of the water upstream and the quality requirements of the water downstream $f$ (for Industrial or drinking purposes)\} are determined. The difference between the two figures determines the tolerance levels at the point of discharge. The second method takes account of individual site factors. Clearly, a small tannery with a high dilution factor should be seen in more favorable light than a large effluent volume with a relatively lower dilution factor. The limits imposed should always relate to the volume of effluent and the total weight of pollutants. If better housekeeping reduces the volume of water used, thus increasing the concentration, the limits can be reasonably relaxed.

The effect of excessive pollutant levels commonly found in tannery effluents can be severe. The main problems presented by those components are summarized together with an outline of the methods used by authorities to determine the levels of those components in effluent.

\section{Objectives}

\section{General Objective}

- $\quad$ To study the effect of potentially toxic elements from contaminated sewage water on soil, water and potato plants.

- 3.2.Specific objectives

- To determine the concentration of the heavy metals in plants (like As, $\mathrm{Cu}, \mathrm{Ni}, \mathrm{Fe}, \mathrm{Mn}, \mathrm{Zn}, \mathrm{Al}, \mathrm{Cr}, \mathrm{Ni}$ )

- To determine the concentration of the heavy metals in water (like As, $\mathrm{Cu}, \mathrm{Ni}, \mathrm{Fe}, \mathrm{Mn}, \mathrm{Zn}, \mathrm{Al}, \mathrm{Cr}, \mathrm{Ni}$ )

- To determine the concentration of the heavy metals in soils (like $\mathrm{As}, \mathrm{Cu}, \mathrm{Ni}, \mathrm{Fe}, \mathrm{Mn}, \mathrm{Zn}, \mathrm{Al}, \mathrm{Cr}, \mathrm{Ni}$ )

\section{Materials and Methods}

\subsection{Description of Study Area}

The study was conducted in the up and down-stream surrounding areas of Sheba tannery. Sheba tannery is found in Wukro, which is $45 \mathrm{~km}$ from Mekelle, the capital city of Tigray region.

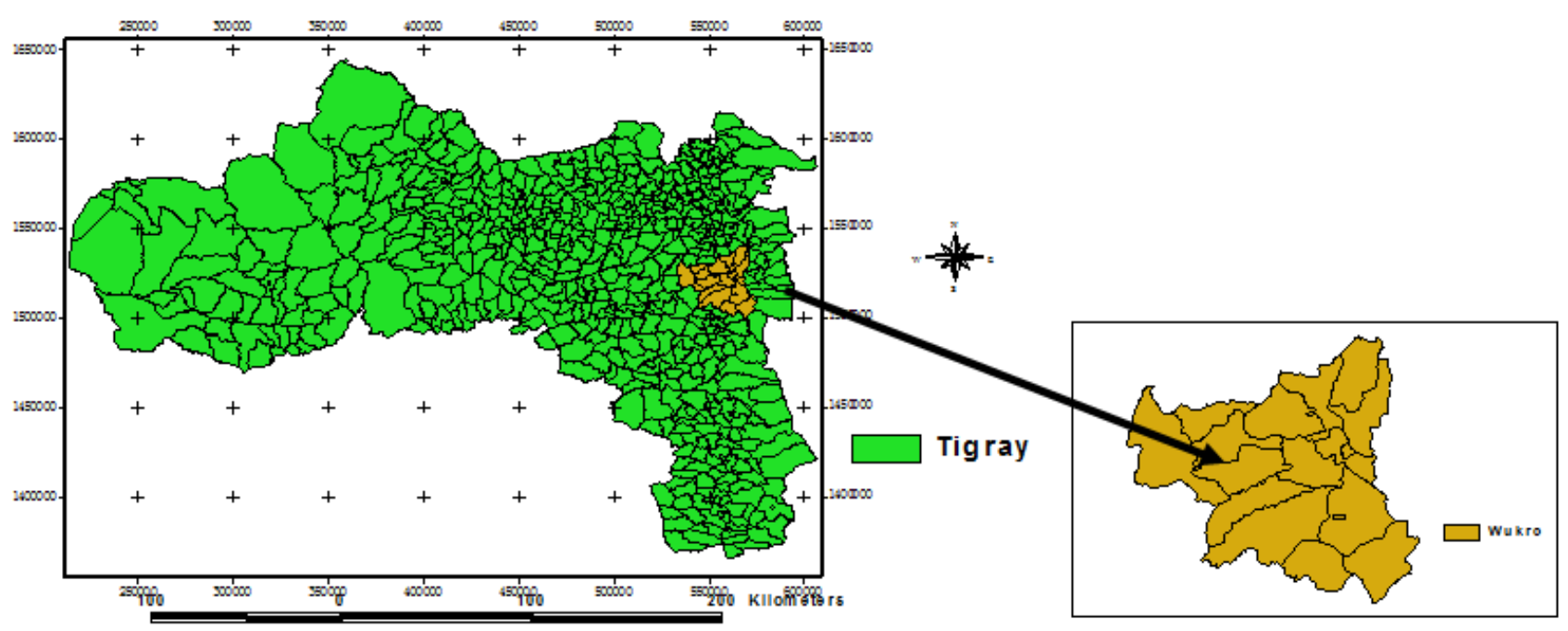

Figure 1. shows map of the study area.

\section{Sample and Sampling Method}

Samples of waste water from the sewage drain were collected before and after the addition of water from the leather complex. About 40 sites growing potato were selected for soil and plant sampling. Fields at 20 sites were irrigated with contaminated sewage water and at remaining 20 sites with groundwater. Soil samples were collected downstream) within $300 \mathrm{~m}$ radius of the tannery. Samples were collected in triplicates and at three depth levels; 0-15 $\mathrm{cm}, 15-30 \mathrm{~cm}$ and $30-45 \mathrm{~cm}$. For comparative studies and in order to obtain reference soil samples, the same sampling method and depths were used to collect samples. (What time of the year was the study carried out? A seasonal variation is possible. The results can only be representative for two period of the year) 


\subsection{Experimental}

The soil samples were air dried and passed through a2-mm sieve and extracted using mixture of nitric and hydrochloric acids. After measuring the $\mathrm{pH}$ and electrical conductivity, about $5 \mathrm{ml}$ of distilled $\mathrm{HNO}_{3}$ was added. For the elemental analysis $250 \mathrm{ml}$ of water was air or sun (check) (what's missing?) dried in a beaker. About $10 \mathrm{ml}$ of distilled $\mathrm{HNO}_{3}$ was added by washing the sides of the beaker. It was again heated till $2-3 \mathrm{ml}$ of sample remain. About $3 \mathrm{ml}$ of $\mathrm{HClO}_{4}$ was added and digested on a hot plate till 2-3 ml sample remained in the beaker. The final volume was made to $10 \mathrm{ml}$ and was analyzed on atomic absorption spectrometer. Elemental analysis of soil was done by extracting the soil with ammonium acetate Leaf and tuber samples of potato and onion were collected, washed, dried, and prepared for analysis. Samples $(0.5 \mathrm{~g})$ was taken in a digestion tube, $5 \mathrm{ml}$ of $\mathrm{HNO} 3$ (subscript 3 ) was added to it and were kept (overnight). It was digested at a constant temperature. When $2-3 \mathrm{ml}$ of the sample remained, it was cooled down and $2 \mathrm{ml}$ of $\mathrm{H}_{2} \mathrm{O}_{2}$ were added and again digested till 1-2 $\mathrm{ml}$ of sample remained. Total volume was made to $10 \mathrm{ml}$ and analyzed on atomic absorption spectrophotometer

\section{Results and Discusssion}

\subsection{Composition of Irrigation Water}

Average values (locations and periods) of $\mathrm{Cu}, \mathrm{Fe}, \mathrm{Mn}, \mathrm{Zn}$, $\mathrm{Al}, \mathrm{As}, \mathrm{Cr}$ and $\mathrm{Ni}$ were $0.41,20.1,0.39,2.25,4.03,0.04$, 8.37 and $0.26 \mu \mathrm{g} \mathrm{ml}^{-1}$ in waste water of (Genfel River) around the tannery and $0.01,0.13,0.004,0.07,0.08,0.01$, 0.006 and $0.005 \mu \mathrm{g} \mathrm{ml}^{-1}$, respectively in ground (tube well) waters(Table 1). Due to disposal of industrial effluents, the waste waters have higher contents of $\mathrm{Cu}$ by 42 times, Fe by $155, \mathrm{Mn}$ by $98, \mathrm{Zn}$ by 31 , Al by 50 , As by $4, \mathrm{Cr}$ by 1400 and $\mathrm{Ni}$ by 52 times over the tube well waters. Although after the disposal of water from leather complex the contents of almost all the elements were increased, the spectacular increase was observed in $\mathrm{Cr}$ which was higher by 2333 times as compared to ground water. Therefore, the content of $\mathrm{Cr}$ is a matter of concern and could become a potential hazard for crops irrigated with this water and it may also pollute the shallow underground waters. Since the water consumed by villagers is drawn from the shallow depth hand pumps, there is a need to monitor the chromium status of hand pump waters installed along the drain to prevent the human/animal health hazards.

\subsection{Effect of Sewage Irrigation on Element Concentrations and Different Elements in Soils}

The average contents of $\mathrm{Cu}, \mathrm{Fe}, \mathrm{Mn}, \mathrm{Zn}, \mathrm{Al}, \mathrm{As}, \mathrm{Cr}$ and $\mathrm{Ni}$ in soils receiving Tube well water were $0.99,13.8,14.3,2.9$, $3.6,1.9,0.81$ and $0.56 \mathrm{mg} \mathrm{kg}-1$ (superscript -1 ), respectively which were found to increase to $4.2,39.7,18.9,14.7,6.5$, 2.09, 1.72 and $1.27 \mathrm{mg} \mathrm{kg-1} \mathrm{(superscript} \mathrm{-1)} \mathrm{in} \mathrm{soils}$ receiving sewage water which showed accumulation to the extent of $4.2,2.9,1.3,5.1,1.8,1.1,2.1$ and 2.3 times, respectively over the adjoining fields irrigated with tube well waters. Vertical distribution of micronutrients in soils showed that $\mathrm{Cu}$ was generally retained in surface layer where the differences between sewage irrigated and tube well irrigated soils were more than 4 times. However, the difference decreased at lower depths.

The Fe content of the soils irrigated with sewage water was higher than that irrigated with tube well water throughout the depth of the profile studied up to $60 \mathrm{~cm}$. It indicated that in addition to surface layer the $\mathrm{Fe}$ is also accumulated in sub-surface layers of the coarse textured soils. The extent of accumulation depended upon the use of industrial waste water. Some facts observed that continuous application of sewage water lead to the accumulation of Fe in surface soils but vertical movement was higher in light textured soils. Manganese content in sewage irrigated soils was higher than tube well irrigated soils at all the depths. The zinc content in upper 0 to $15 \mathrm{~cm}$ soils was 5 times and in lower depths 2 to 3 times higher in sewage irrigated soils. Higher content in upper 0 to $15 \mathrm{~cm}$ soils was also due to use ofZnSO4 (subscript 4) as fertilizer. The content of Al was higher in sewage irrigated soils; however, there was no difference in as content of the soils. The differences in the contents of $\mathrm{Cr}$ and $\mathrm{Ni}$ were more predominant up to $30 \mathrm{~cm}$ soil depth. The build up(buildup) of $\mathrm{Cr}$ and $\mathrm{Ni}$ were also observed up to $30 \mathrm{~cm}$ depth with the application of sewage water. As no external application of any element except zinc was done by the farmers, the differences were mainly due to the application of sewage water. Since most of the elements are mainly retained up to $30 \mathrm{~cm}$ depth (the rooting zone of most of the crops) it is likely that plants may absorb excessive amounts of these elements.

\subsection{Effect of Sewage Irrigation on Element Concentrations in Potato and Onion Plants}

Average copper concentrations in leaves and tubers were 5.9 and $4.4 \mathrm{mgkg}^{-1}$ in ground water irrigated fields and increased to 9.3 and $5.6 \mathrm{mg} \mathrm{kg}^{-1}$ in sewage water irrigated fields. Against 4.2 fold increase in soils the increase in leaves and tubers were 1.6 and 1.3 folds respectively with the application of sewage water. The copper concentrations were higher in leaves than in tubers. Average iron concentration increased from 513 to $555 \mathrm{mg} \cdot \mathrm{kg}^{-1}$ in potato and from 91 to $125 \mathrm{mg} \mathrm{kg}^{-1}$ in onion with the application of sewage water over the adjoining fields irrigated with ground water. The concentrations were 5 folds higher in leaves than in tubers. Manganese concentrations in leaves and tubers increased from 389to $424 \mathrm{mg} \mathrm{kg}^{-1}$ and 16.9 to $20.9 \mathrm{mg} \mathrm{kg}$-1(superscript $-1)$, respectively with the application of sewage water. The pattern of build up was almost similar in soils and plants. However, the concentration was spectacularly higher in leaves than in tubers. Zinc concentration increased from 30.2 to $70.6 \mathrm{mg} \mathrm{kg}-1$ (superscript) in leaves and from 28.6 to 34.7 mg kg-1 (superscript -1) in tubers with the application of sewage water. The (buildup) was 2.3 folds in leaves and 1.3 
folds in tubers against the 5.1 fold increase in zinc content of soils. This indicated that zinc is not being absorbed proportionally to its content in soils by the plants. The Al content in leaves increased from 407 to $426 \mathrm{mg} \mathrm{kg}-1$ (superscript -1) and in tubers from 84 to97 $\mathrm{mg} \mathrm{kg}-1$ (superscript -1) with the application of sewage water. Al concentration in leaves were more than 4 times higher than in tubers indicating that most of it is retained in the nonedible (leaves) part of the plant. The As content increased from 12.1 to $16.5 \mathrm{mg} \mathrm{kg}-1$ (superscript -1) in leaves and from 8.5 to $8.6 \mathrm{mg} \mathrm{kg}-1$ (superscript -1 ) in tubers with the irrigation of sewage water. The increase in As content with the application of sewage water was more in leaves than in tubers. The $\mathrm{Cr}$ content increased from 7.6 to $13.8 \mathrm{mg} \mathrm{kg}-1$ (superscript -1) in leaves and from 4.8 to $8.5 \mathrm{mg} \mathrm{kg}-1$ (superscript) in tubers. Hence concentrations in sewage irrigated field were nearly doubled than those in irrigated by ground water. The content of $\mathrm{Cr}$ was almost double in soils as well. This indicated that application of sewage water is building up the $\mathrm{Cr}$ content in soils and it is being absorbed by the plants proportionally. The buildup was similar both in edible and non-edible parts of the plant. Similar is the situation in case of $\mathrm{Ni}$ where its concentration in leaves increased from 2.8 to $7.3 \mathrm{mg} \mathrm{kg}-1$ (superscript -1) and from 1.21 to $2.50 \mathrm{mg} \mathrm{kg}-1$ (superscript -1 ) in tubers. The (buildup) was 2.3 fold in soil, 2.6 fold in leaves and 2.1 folds in tubers.

The data indicated that irrigation with sewage water mixed with effluents of the leather complex resulted in the maximum (buildup) of zinc and copper. However, their absorption by the plants was not proportional to the build up(buildup) in soils. But in case of $\mathrm{Cr}$ and Ni the absorption by plants and their distribution in edible and (nonedible) portions was proportional to their build up in soils. Hence $\mathrm{Cr}$ and $\mathrm{Ni}$ seem to be the element polluting the fields irrigated by sewage water and may become health hazards for consumers of crops grown on the fields irrigated by sewage water contaminated with effluent of leather complex.

Table 1. Composition of irrigation water $(\mu g \mathrm{ml}-1)$.

\begin{tabular}{lllll}
\hline \multirow{2}{*}{ Elements } & \multirow{2}{*}{ Ground } & \multicolumn{2}{l}{ Sewage water } & \\
\cline { 3 - 5 } & & Before LCW* & After LCW & Average \\
\hline $\mathrm{Cu}$ & 0.01 & 0.40 & 0.42 & 0.41 \\
$\mathrm{Fe}$ & 0.13 & 16.4 & 24.2 & 20.1 \\
$\mathrm{Mn}$ & 0.004 & 0.35 & 0.44 & 0.39 \\
$\mathrm{Zn}$ & 0.07 & 1.99 & 2.51 & 2.25 \\
$\mathrm{Al}$ & 0.08 & 3.24 & 4.82 & 4.03 \\
$\mathrm{As}$ & 0.01 & 0.04 & 0.04 & 0.04 \\
$\mathrm{Cr}$ & 0.006 & 2.72 & 14.03 & 8.37 \\
$\mathrm{Ni}$ & 0.005 & 0.19 & 0.35 & 0.26 \\
\hline
\end{tabular}

*LCW $=$ Leather Complex Water

Table 2. Heavy metal concentrations in plant and soil samples (mg kg-1).

\begin{tabular}{|c|c|c|c|c|c|c|}
\hline \multirow{3}{*}{ Elements } & \multicolumn{2}{|c|}{ Soils (mg kg-1 superscript -1) } & \multicolumn{4}{|c|}{ Plants (mg kg-1 $)$} \\
\hline & IGW* & ISW** & potato & & Onion & \\
\hline & & & $\mathrm{IGW}^{*}$ & $\mathrm{ISW}^{* *}$ & $\mathrm{IGW}^{*}$ & ISW** \\
\hline $\mathrm{Cu}$ & 0.99 & 4.2 & 5.9 & 9.3 & 4.4 & 5.6 \\
\hline $\mathrm{Fe}$ & 13.80 & 39.7 & 513.0 & 555.0 & 91.0 & 125.0 \\
\hline $\mathrm{Mn}$ & 14.30 & 18.9 & 389.0 & 424.0 & 16.9 & 20.9 \\
\hline $\mathrm{Zn}$ & 2.90 & 14.7 & 30.2 & 70.6 & 28.6 & 34.7 \\
\hline $\mathrm{Al}$ & 3.63 & 6.5 & 407.0 & 426.0 & 84.0 & 97.0 \\
\hline As & 1.87 & 2.1 & 12.1 & 16.5 & 8.5 & 8.6 \\
\hline $\mathrm{Cr}$ & 0.81 & 1.7 & 7.6 & 13.8 & 4.8 & 8.5 \\
\hline $\mathrm{Ni}$ & 0.56 & 1.27 & 2.8 & 7.3 & 1.2 & 2.5 \\
\hline
\end{tabular}

IGW - Irrigated with Ground Water

**ISW - Irrigated with Sewage Water

\section{Conclusion and Recommendation}

Through this study, it is clear that the industrial waste has substantially changed the irrigation water quality diverted from the rivers and consequently, some chemical elements also increased in the soil of the irrigated farmlands. EC of Genfel River was differentiated to be a slightly restricting. As onion is a major vegetable grown in local area, the prevailing EC values might causes a potential $10 \%$ yield decline. Leaching is needed to avoid the associated long term risks. Some of the crops grown in the local farms irrigated by Genfel River (like onion, carrot, potato and cucumber) would also be sensitive to the prevailing concentration of potentially toxic elements content of GenfelRiverswere higher and would pose permeability problems (surpassed the safe limits). Since the root system of most crops develop best in the upper $30 \mathrm{~cm}$ of the soil (FAO Soil Bulletin 55, 1985), the existing higher levels of potentially toxic elements irrigation water in the soils render problems of drainage, tillage and surface crusting and these could affect crop yield. The existence of Vertisol also pronounces the effect of low infiltration because of the swelling and shrinkage of soil containing clays minerals and the subsequent collapse of soil pores (Levy and Miller, 1997). If sprinkler irrigation method is applied in the future, the concentration of potentially toxic elements could also cause foliar injury on the growing local vegetable like tomato, pepper, potato and maize (Mass, 1990). The higher HCO3- (superscript 3-)concentration in (Genfel River) irrigated soil solution can harm the mineral nutrition of plants, since excesses HCO3- affects the uptake and metabolism of nutrients. Higher soil $\mathrm{pH}(9.08-9.36)$ values was found in Genfel River) irrigated farmland soils. Such values of $\mathrm{pH}$ in farm soils may have a profound effect on availability of plant nutrients, as micronutrients, for instance; iron, manganese, zinc, copper, and cobalt are less available at a $\mathrm{pH}>8.5$ (Ayers and Westcott, FAO 1985). All 
chemical parameters analyzed in the surface composite soil samples were found to be higher in farmlands irrigated by effluent mixed irrigation water of the two rivers. This indicates that the trend of the chemicals, which are important for suitable irrigation, is alarmingly increasing. The problems seems exacerbate in the town farmlands soil type, as Ayers and Westcott (1985) state low quality irrigation water is hazardous on clayey soil (particularly in Genfel irrigated farmlands), while the same water could be used satisfactorily on sandy and/or permeable soils. Since quality of water is an important priority for both environmental and economic reasons, it is vital that the fate of wastewater effluent in the surrounding rivers is to be well understood. Soil permeability problems can be improved by blending the fresh water of the Genfel River with the effluent contaminated water, in particular to Genfel River. Blending proportion and implementation could be guided by the local agricultural administration. Other practices that can be done at individual farm level may include cultivation and deep tillage, increasing duration of irrigation, changing the direction of irrigation to reduce slope, collecting and recirculation of runoff water, using organic residue, using soil or water amendments (gypsum, elemental sulfur etc.) and changing irrigation water supply. Analysis of effluents only by the parameters selected under this research study is not adequate. Heavy metals, Organic and synthetic pollutants are suspected to be discharged with the liquid wastes and are rarely analyzed and thus it demand further investigation to assess their effects on the activity of soil microorganisms, crop productivity and crop quality. Assessment on the trend of the farmlands yield should be conducted in order to have better perspective of the effluents impact on soils. It also creates awareness (to factories officials and farmers) of the problems, thereby urging to seek for corrective measures. Recent reports from the health center (2006) of the town indicated that the nearby community is frequently exposed to upper respiratory tract infection, asthma, malaria and skin diseases. Studies need to be conducted on the water quality and emission value of particulate matter in to the air in order to assess their clear impact on health. Since wukro (Wukro) is as a city of industrialization by the Tiigray National Regional State of Ethiopia, all concerned bodies must focus on appropriate industrial waste management strategy and integrated with the industrial development.

\section{Acknowledgments}

This study was done in the Department of Chemistry, Mekelle University, Ethiopia. The author is grateful to Dr. KEBEDE NIGUSSIE giving me valuable information. The author would like to thank IUC VLIR for finical support providing the necessary facilities to carry out this work.

\section{References}

[1] AlemtsehayeBirru. 2002. Assessment of the fertility and pollution status of irrigated vegetable farms around Addis Ababa city. Final report. Addis Ababa Agricultural Office, Addis Ababa, Ethiopia.

[2] Kalu 'Woreda' (province) Agricultural Activities Annual Report. June, 2006.

[3] Ayers, R.S.. 1977. Quality of Water for Irrigation. Journal of the Irrigation and Drainage Division. ASCE. Vol. 103. No. IR2. P. 140.

[4] Ayers, R. S. and D. W. Westcott, FAO 1985. Water Quality for Agriculture. Irrigation and Drainage Paper No. 29, Rev.1.Food and Agriculture Organization of the United Nations. Rome, Italy.

[5] Biswas, A, 1998. Environmental Planning Management and Development. PP.208 - 402.

[6] FAO. 1985. Soil Bulletin 55, Guidelines: land Evaluation for Irrigated Agriculture. Roma, Italy: Food and Agriculture Organization of The United Nation.

[7] FAO.1985. Soil Bulletin 42, Soil Survey Investigation for Irrigation. Rome, Italy. Food and Agriculture Organization of The United Nation.

[8] FAO. 1998. Conservation and Development of Dry Land Resources. (CD-ROM). Land and Water Digital Media Series No. 2. Rome: FAO.

[9] Levy GJ, Miller WP (1997) Aggregate stability of some southern US soils. Soil SciSoc Am J 61:1176-1182.

[10] Mass (1987) Salt Tolerance of Plants. CRC Handbook of Plant Science in Agriculture. B.R. Cristie (ed.). CRC Press Inc.

[11] Mass (1990) Crop Salt Tolerance. Agricultural Salinity Assessment and Management Manual. K.K. Tanji (ed.). ASCE, New York. pp 262-304.

[12] National Urban Planning Institute. 2001. Report On: Development Plan of wukro Town.

[13] Richards, L. A. (ed.) (1954). Diagnosis and Improvement of saline and alkaline Soils. United States Department of Agriculture. Agriculture Handbook No. 60. Washington, D.C., USA.

[14] U.S. Salinity Laboratory Staff, 1954. Diagnosis and improvement of saline and alkali soils.

[15] Westcot, D. W. and R. S. Ayers. 1985. Irrigation Water Quality Criteria, In G. S. Pettygrove and T. Asano (eds.) Irrigation with Reclaimed Municipal wastewater: A Guidance Manual. 